parison with some of the other projects already undertaken for the preservation and effective use of our natural resources. The procedures which will be based upon the use of the Roster are at once effective and truly democratic. The time has come when our nation must be efficient. The National Roster of Scientific and Specialized Personnel is certainly a necessary tool of an effective democracy."

\section{University Course for Officer Cadets}

Is order to provide a steady flow of young men with the necessary mathematical and scientific knowledge into the Officer Cadet Training Units, the War Office has arranged for 1,200 men to be trained at selected universities every six months. By this means it is hoped to meet particularly the demands of the more technical branches, such as the Royal Engineers, Royal Corps of Signals and Royal Artillery. The men will be selected at examinations conducted in June and November by the Civil Service Commissioners, after which they will serve in a training unit for three months before proceeding to the selected university. The Government is to make a grant to the universities concerned to cover the cost of these courses. The age limits for those wishing to take the examination in November are $18-18 \frac{1}{2}$ by the end of this year; those taking it in June 1941 must be within the limiting ages on July 1, 1941. The first courses, to begin in October next, will be filled by candidates who were between the requisite age limits on June 1, 1940 , and nominated by head masters or commanding officers.

\section{Rumania's Cultural Losses}

Among the consequences of Rumania's loss of territory (Bessarabia and Bukovina to Russia, the Dobrudja to Bulgaria and part of Transylvania to Hungary) are the cultural changes taking place within the ceded lands. The universities of Cernauti (Czernowitz) and Chishinau (Kishenev) and the Observatory at Dubosarii Vechi have been transferred to the Soviet Union. In the Dobrudja there is no institution of university rank, but there are important local high schools. The greatest cultural losses are in Transylvania, where there are many important educational institutions, including the Universities of Kluj (Klausenburg) and Oradea Mare (Grosswardein) and the headquarters and branches of several learned societies. At Kluj, the capital of Transylvania, the University had famous medical and science faculties, and its library was the largest provincial one in the country. Two celebrated museums are lost, namely, the Transylvanian Ethnographical Museum and another with general and local natural history collections.

It is in this part of Rumania that the largest German minority is mainly settled and centres of German culture now pass back to Hungary, though the town of Sibiu (Hermannstadt) with its Brukenthal Museum and German library remain in Rumania. A number of Rumanian men of science and learning have had to relinquish their posts and have been transferred to Bucharest and other places in diminished Rumania. Their colleagues and fellow scientific workers in other lands extend their sym pathy, trusting that their work for mankind may soon be resumed in happier circumstances.

\section{Britain's Supplies of Feeding-stuffs}

IN view of the actual and prospective shortage o: feeding-stuffs in Britain, attention may be directec to the comprehensive study of the situation made by Dr. Norman C. Wright, director of the Hannar Dairy Research Institute, in the Empire Journal oj Experimental Agriculture for July 1940 (see alsc NATURE of August 24, p. 251). In this study, which gives detailed trade statistics for the period 1934-8 the author stresses the great part played by ou grasslands in providing food for livestock; grazing and hay together supply just under 60 per cent of the protein and starch equivalents consumed. To. gether with the products of arable land, our home supplies constitute about three quarters of the tota] available. Unfortunately, however, grass, including hay, is essentially a seasonal product, and the question of supplies in winter during war-time becomes very serious, especially in respect of pigs and poultry, which are mainly fed on cereals and concentrates, and of which we import 70-75 per cent of our requirements. Owing to shortage of shipping and to currency restrictions, supplies of all imported feeding-stuffs will be much reduced next winter, and it seems likely that the pre-War proportions of cereal and oil-seed imports will remain unaltered.

The choice of imports and of crops to be grown for home production should be governed primarily by accessibility of overseas producing areas, by suitability for storage, and by the practicability of diversion to human consumption. The ploughing-up policy, which has already added $2,034,000$ acres to our arable land, will eventually increase the supplies of nutrients available for winter feeding, and when the ploughed-up land reverts to pasture there will be a marked increase in productivity. Maximum economy in the use of feeding-stuffs demands a definite order of priority in the allocation of supplies to different classes of livestock. Cereals are the most economical supplies of energy to the human population, and in war-time animal products should be regarded essentially as sources of the 'protective' foods, namely, first-class protein, minerals and vitamins. Milk and milk products are of outstanding value in this respect: eggs are of special value in cooking and for invalid dietaries; meat is of secondary importance; bacon and butter are valuable, but not essential, sources of fat. Everything points to the importance of maintaining our dairy herds and of increasing our imports of cheese, eggs, and bacon from Empire countries, though at present these are exporting practically up to the hilt.

After satisfying the requirements of milch cows, Dr. Norman Wright thinks that feeding-stuffs should be preferentially allocated to poultry and pigs, and not, as has been officially intimated, to beef cattle and sheep, for these provide less valuable animal products at greater feed-cost and can be largely maintained on grass and coarse fodders. The official 